Vol. 2, No. 1 (2021):44-56

http://journalsttcipanas.ac.id/index.php/NPTRS/

p-ISSN 2722-9726, e-ISSN 2722-9718

Published by Cipanas Theological Seminary

\title{
Kajian Singkat tentang Injil dalam Perjanjian Lama
}

\author{
Barnabas Ludji \\ Email: nabasludji@gmail.com
}

\begin{abstract}
Abstrak
Topik mengenai kaitan antara Perjanjian Lama (PL) dan Perjanjian Baru (PB) menjadi perdebatan di antara para ahli biblika. Pertanyaan mengenai kaitan antara soterioli dalam PL dan PB pun menjadi bagian dari perdebatan dalam studi biblika. Tulisan ini menelaah bagaimana konsep Injil dari PL harus dipahami. Metode semantik akan diterapkan dalam beberapa teks Kitab Yesaya untuk menjawab pertanyaan tersebut
\end{abstract}

Kata Kunci: Injil, Perjanjian Lama, Yesaya, Mazmur, Makna

\section{Pendahuluan}

Ketika orang membaca topik yang hendak saya jelaskan dalam tulisan ini, mungkin ada orang yang bertanya-tanya, apa ya, ada Injil dalam Perjanjian Lama (PL)? Bukankah yang dimaksudkan dengan Injil itu hanya ada pada Perjanjian Baru (PB)? Bukankah Injil hanya berkaitan dengan figur dan karya Tuhan Yesus sebagai Juru Selamat? Bukankah dalam PL itu penuh dengan cerita-cerita, peraturan-peraturan, ketetapan-ketetapan yang bernuansa kekerasan dan kekejaman? Di sana ada hukum nyawa ganti nyawa, mata ganti mata, ada hukuman mati, ada perintah untuk memusnahkan musuh-musuh umat dan lain-lainnya. Bukankah ada juga pendeta-pendeta, bahkan teolog yang mempunyai pandangan yang dualistis terhadap Alkitab Kristen. Menurut mereka dalam khotbah-khotbahnya, PL itu hanya berbicara keadilan, sedangkan PB itu sangat menekankan kasih. Seolah-olah Allah yang diberitakan para nabi atau imam itu tidak pernah mengasihi umat-Nya, apalagi bangsa-bangsa lain. Seolah-olah Allah itu tidak pernah mengampuni umat-Nya dan apalagi bangsa lain. Seolah-olah, Allah yang diberitakan PL itu tidak menebus dan menyelamatkan umat-Nya dan apalagi bangsa-bangsa 
Vol. 2, No. 1 (2021):44-56

http://journalsttcipanas.ac.id/index.php/NPTRS/

p-ISSN 2722-9726, e-ISSN 2722-9718

Published by Cipanas Theological Seminary

lain. Yang mendorong saya untuk meneliti tema ini adalah ucapan pendeta jemaat saya (Pdt. Alm. Abner Pada), ketika saya masih duduk di bangku SMP. Ia mengatakan bahwa pada ayatayat awal teks Sepuluh Firman yang terdapat dalam Keluaran 20 itu ada Injilnya. Sepuluh hukum didahului oleh Kabar Baik (Injil), yaitu proklamasi bahwa Tuhanlah yang telah membebaskan bangsa Israel dari perbudakan di Mesir.

\section{Istilah Injil}

Dalam PL, ditemukan kata-kata Ibrani yang berasal dari akar kata $b s r$ sebanyak 30 kali. Dari 30 kata itu, 14 kali dalam bentuk kata kerja piel, sekali dalam bentuk kata kerja hitpael, 9 kali dalam bentuk partisipel, 6 kali sebagai kata benda. Istilah ini berasal dari bahasa Akad, bassuru/passuru dan bussurtu yang berarti, "membawa suatu berita." Istilah Ibrani, bassar juga berarti, kabar/berita. Pada mulanya istilah-istilah di atas hanya berarti "kabar." Istilah-istilah tersebut akan memberi arti lengkap bila istilah-istilah di atas dikaitkan dengan kata-kata yang lain. Misalnya, bussurat lumnim (Akad) dan bissar ra'a (Ibrani) yang berarti, "kabar buruk," bussurat dumqim (Akad) dan bassar tov (Ibrani) yang berarti "kabar baik," bussurat hada yang berarti "kabar sukacita."

Akan tetapi apabila kata bissar ditinjau dari akar kata bahasa Semit pada umumnya (Akad, Ugarit) dalam bentuk kata kerja $b s r,{ }^{1}$ Etiopia absara, Arab, bassara, dan Aram, bsr, maka kata tersebut selalu berarti "kabar baik" atau "kabar sukacita." Karena itu, kalau bahasa Ibrani bissar dikaitkan dengan kata tov, maka itu bermaksud menekankan kabar baik itu (2 Sam. 18:27; 1Raj. 1:42). ${ }^{2}$

\section{Makna Bassar secara Sosiologis}

Istilah bissar ini sebenarnya berasal dari dunia sekuler. Kata $b s r$ dalam pengertian sekuler bisa ditemukan antara lain dalam Kitab Samuel dan Raja-raja. Pertama, dalam kisah tentang kematian Absalom anak Daud. Baik Daud sebagai ayah Absalom, maupun utusan atau

\footnotetext{
${ }^{1}$ Bandingkan Friedrich Baumgärtel, euaggelizomai, euaggelion, proeuaggelizomai, euaggelistes, TDNT Vol. 2., ed. Gerhard Friedrich (Grand Rapids: Eerdmans, 1964), 707. Kata bisar dalam Perjanjian Lama, pada umumnya selalu berarti "memberitakan kabar baik (Injil)". Kata ini diambil dari 1 Raj. 1:42. Juga mengenai "kabar baik (bissar)" mengenai kelahiran seorang anak (Yer. 20:15).

${ }^{2}$ O. Schilling, Bsr; besorah dan bdl - galah, TDOT Vol. 3., ed. G. Johannes Botterweck, Helmer Ringgren (Grand Rapds: Eerdmans, 1977), 313.
} 
Vol. 2, No. 1 (2021):44-56

http://journalsttcipanas.ac.id/index.php/NPTRS/

p-ISSN 2722-9726, e-ISSN 2722-9718

Published by Cipanas Theological Seminary

pembawa berita kematian Absalom mengharapkan bahwa berita itu merupakan kabar baik. Daud mengharapkan kabar baik yang berupa berita bahwa anaknya Absalom masih hidup. Sementara pembawa berita mengharapkan bahwa berita kematian Absalom itu merupakan kabar baik bagi Daud. Kedua pihak, utusan (2 Sam. 18:19,20) dan Daud (2 Sam. 18:25,26) berbicara tentang kabar sukacita. Keduanya menggunakan kata $b s r$ dalam berbagai bentuk seperti, bassera, bessora, bissar, dan lebasser yang semuanya berarti, "kabar sukacita.” Bagi para utusan, berita kemenangan atas pemberontak adalah kabar baik bagi Daud. Sedangkan bagi Daud, kabar sukacita itu adalah berita kemenangan atas pemberontak dan berita tentang keselamatan Absalom. Kedua, berita tentang kematian Saul yang disampaikan kepada Daud (2 Sam. 4:10). Kabar sukacita diproklamasikan kepada para ilah dan bangsa Filistin. Dengan demikian kata bissar dalam pengertian umum adalah kabar sukacita dari medan perang atau berita kemenangan atas musuh-musuh. ${ }^{3}$ Orang yang membawa kabar baik atau kabar sukacita disebut mebasser (utusan).

Istilah bsr dalam Septuaginta diterjemahkan dengan kata, euaggelizesthai bukan euaggelion. Walaupun demikian arti dasar kata euaggelion jelas berakar pada kata bissar/euaggelizesthai.

Transisi penggunaan kata bisar dari pengertian sekuler ke dalam kehidupan religius mungkin dapat ditemukan dalam 1 Samuel 31:9. Hal itu tampak ketika orang Filistin meraih kemenangan atas orang Israel di bawah pimpinan Saul. Orang Filistin membawa kepala dan pedang Saul untuk dipertontonkan di negeri orang Filistin. Kabar kemenangan itu diumumkan kepada berhala-berhala dan bangsa itu. ${ }^{4}$ Hal yang sama ditemukan dalam Mazmur 68:11.

\section{Kata bissar dalam Pengertian Teologis}

Pertama, penggunaan kata bissar dalam arti perbuatan atau karya penyelamatan Allah. Arti teologi dari kata bissar kita temukan dalam bentuk kata kerja dan kata benda. Pengertian teologis dari kata tersebut, kita temukan dalam Kitab Mazmur dan kitab Nabi-nabi. Mazmur 68 berbicara tentang para utusan yang membawa kabar baik tentang kemenangan Israel atas musuh-musuhnya. Kemenangan itu diyakini sebagai kemenangan Allah. Karena itu, Allah

\footnotetext{
${ }^{3}$ Friedrich Baumgärtel, 707.

4 Ibid. 708.
} 
Vol. 2, No. 1 (2021):44-56

http://journalsttcipanas.ac.id/index.php/NPTRS/

p-ISSN 2722-9726, e-ISSN 2722-9718

Published by Cipanas Theological Seminary

memberikan nyanyian kemenangan untuk dinyanyikan oleh sekelompok perempuan. Isi nyanyian itu adalah kabar baik/kabar keselamatan. Para utusan perempuan yang membawa kabar sukacita ini analogi dengan perempuan-perempuan yang menyanyikan kemenangan Saul dan Daud dalam 1 Samuel 18:7 dst. Mazmur 68:12 bukan kabar kemenangan yang ditujukan kepada pendengar yang spesifik, melainkan merupakan kabar sukacita tentang karya penyelamatan Allah, suatu puji-pujian mengenai Allah. Mazmur 68:11 menggambarkan Tuhan sebagai pelindung serta pembela orang, khususnya yang rentan yang tertindas. ${ }^{5}$ Inilah yang dimaksudkan dengan 'khabar baik' dalam ayat 12. Dari sudut pandangan inilah kita mengerti bahwa $b s r$ dalam teks-teks kultus seperti Mazmur 40:10; 96:2 memiliki arti kabar sukacita tentang perbuatan besar Tuhan dan sebagai pengakuan iman yang muncul dari sukacita keagamaan yang mendalam. Mazmur 40:10,11 merupakan nyanyian baru yang Tuhan berikan ke dalam mulut pemazmur untuk mengabarkan Injil (bissar) Tuhan, yaitu: keadilan (tsedeq), damai sejahtera (emunateka =aman), keselamatan (yesyu'a'), kasih setia (khesed), dan kebenaran ('emet//tsedeq). Jadi yang dimaksudkan dengan Injil di sini ialah, kabar kesukaan yang disimpulkan dengan kata-kata, keadilan, damai sejahtera, keselamatan, kasih setia, dan kebenaran. Menurut Hans Joachim Kraus, Mzm. 40 berasal dari zaman pembuangan di mana Taurat sangat berperan penting dalam kehidupan umat. Pemazmur agaknya menyerap dan mengambil alih berbagai ketetapan tentang korban, upacara-upacara agama dan memelihara hukum-hukum moral serta pelaksanaannya untuk setiap individu. Khususnya peranan kenabian yang dipengaruhi oleh Deuteronomis (Ul. 6:6; 30:1 dst.; Yer. 31:31-34 yang menunjuk kepada Perjanjian Baru (New Covenant). ${ }^{6}$

Kedua, bsr sebagai kabar sukacita. Nahum 1:15 berbicara tentang utusan Injil (mebasser) yang membawa berita sukacita ke Yerusalem yaitu mengenai kejatuhan Asyur.

\section{Injil dalam Kitab Taurat}

Dengan memerhatikan penggunaan kata $b s r$ dalam beberapa teks PL dengan cakupan pemahamannya, maka sebenarnya dalam PL sarat dengan kabar baik (Injil). Misalnya,

\footnotetext{
${ }^{5}$ Marvine Tate, Psalms 51-100, WBC (Dallas: Word Books, 1990), 176.

${ }^{6}$ Hans Joachim Kraus, Psalms 1-150, (Philadelpia: Ausburg, 1978), 427.
} 
Vol. 2, No. 1 (2021):44-56

http://journalsttcipanas.ac.id/index.php/NPTRS/

p-ISSN 2722-9726, e-ISSN 2722-9718

Published by Cipanas Theological Seminary

peristiwa keluaran yang mengawali sepuluh firman (Kel. 20:1-17 dan Ul. 5:6-21). Berita Injil tidak hanya tampak dalam pembukaan sepuluh firman, tetapi juga terdapat dalam berbagai peraturan, ketetapan dan hukum. Misalnya, peraturan-peraturan yang berhubungan dengan perbuatan-perbuatan kemanusiaan yang menyelamatkan dan membebaskan kaum marginal dari penindasan dan kemiskinan. Apabila kita membandingkan Yes. 61:1-2 dengan Im. 25:155, maka yang dimaksudkan dengan tahun rahmat adalah tahun Sabat dan tahun Yobel. Dengan demikian peraturan tahun Sabat ataupun tahun Yobel juga adalah Injil. Bahkan Injil yang terkandung dalam tahun Sabat dan tahun Yobel bersifat kosmos, karena tanah dan ternak pun akan mengalami masa-masa istirahat pada tahun ketujuh (tahun sabat) dan tahun Yobel (tahun kelima puluh). Pada tahun Yobel akan terjadi pembebasan besar-besaran. Semua yang terbelenggu dan tertindas yang kebanyakan para budak atau orang upahan akan dibebaskan dan kembali kepada kaumnya masing-masing. Pada saat itu semua orang kembali menghirup udara bebas tanpa intimidasi, tanpa teror, tanpa penindasan. Semuanya memiliki hak yang sama dalam menikmati berkat Allah. Orang-orang terbelenggu dan tertindas akan menemukan kembali harga dirinya dan keberadaannya sebagai orang yang telah menerima pembebasan dari Allah. Karena itu, tahun Sabat dan tahun Yobel merupakan kabar baik dan kabar sukacita bagi mereka yang sengsara dan yang tertindas.

Perintah-perintah dan ketetapan-ketetapan menyangkut perlindungan bagi kaum miskin dan lemah juga merupakan Injil. Karena dengan berbagai peraturan dan ketetapan itu, hak hidup mereka yang miskin dan lemah dapat terlindungi. Misalnya, Imamat 25:35-39 yang mengandung peraturan yang dapat menopang dan mendukung hak hidup mereka yang miskin dengan cara memberikan pinjaman baik berupa uang maupun berupa barang tanpa memungut riba atau bunga. Peraturan-peraturan semacam ini disampaikan kepada umat ketika muncul kecenderungan memudarnya solidaritas di antara umat. Semuanya tentu merupakan kabar baik bagi mereka yang miskin dan lemah. Karena hakikat berbagai peraturan dan ketetapan adalah keselamatan, kasih, kebenaran dan keadilan, maka berbagai peraturan, ketetapan, dan hukum yang berhubungan dengan masalah-masalah kemanusiaan; yang membebaskan mereka dari penindasan dan eksploitasi sesama; yang membebaskan mereka yang berkekurangan dan miskin; dan yang membebaskan orang dari penderitaan dan kesengsaraan merupakan Injil dalam PL. 
Vol. 2, No. 1 (2021):44-56

http://journalsttcipanas.ac.id/index.php/NPTRS/

p-ISSN 2722-9726, e-ISSN 2722-9718

Published by Cipanas Theological Seminary

\section{Makna Injil dalam Deutero Yesaya dan Trito Yesaya}

Makna Injil dalam kedua bagian Alkitab ini memiliki kaitan yang erat, namun memiliki latar belakang sejarah yang berbeda, yaitu, umat pada masa pembuangan dan sesudah pembuangan.

\section{Injil dalam Deutero Yesaya}

Deutero Yesaya juga mempunyai gambaran yang sama, tetapi Nabi Deutero Yesaya menghubungkan mebasser (utusan) itu dengan janji keselamatan (Yes. 52:7). Ayat ini tidak hanya berhubungan dengan keluaran dari Babel (52:11), tetapi juga berhubungan dengan berita-berita dimulainya dominasi kerajaan Allah. Injil yang dimaksudkan Deutero Yesaya ialah pekerjaan penyelamatan Allah yang berwujud pembebasan bangsa Israel dari pembuangan di Babel. Termasuk juga di dalamnya pembaharuan dan penebusan Allah atas Israel. Kabar baik (Injil) syalom (damai sejahtera) yang meliputi seluruh dimensi kehidupan manusia (bandingkan tafsiran Marie Claire Barth). ${ }^{7}$ Untuk memahami dengan jelas apa yang dimaksudkan dengan Injil menurut Deutero Yesaya, kita perlu mengikuti penjelasan berikut ini.

Bagian kedua dari kitab Yesaya (40-55) merupakan karya seorang nabi yang hidup menjelang akhir pembuangan. Mengenai nama dan pribadi nabi ini tidak diketahui. Panggilan nabi ini berawal dari suara yang berkata "berserulah" (40:6-9). Ayat 9 menggambarkan Sion/Yerusalem sebagai pembawa kabar baik (mebasseret). Menurut Marie Barth, mungkin pembawa kabar baik itu sebagai seorang perempuan yang disuruh menyerukan Injil dari atas Gunung agar kedengaran dari tempat kejauhan. Mungkin juga Sion, Yerusalem sendiri yang dikiaskan sebagai wanita. ${ }^{8}$ Menurut saya, mungkin nabi anonim (Deutero Yesaya) sendiri yang menyerukan atau memproklamasikan khabar baik itu dari Gunung Sion. Persoalannya apakah si nabi itu berada di Babel atau berada di Yerusalem. Tetapi bisa mungkin juga sang nabi sengaja mengadaikan Sion/Yerusalem sebagai pusat tempat di mana Injil disebarkan ke seluruh penjuru alam. Hal ini agaknya masuk akal juga, karena pada masa itu Yerusalem dan Bait Allah

\footnotetext{
${ }^{7}$ Marie Claire Barth, Tafsiran Alkitab: Kitab Nabi Yesaya pasal 40-55, (Jakatra: BPK, 1983), 298.

8 Ibid. 60.
} 
Vol. 2, No. 1 (2021):44-56

http://journalsttcipanas.ac.id/index.php/NPTRS/

p-ISSN 2722-9726, e-ISSN 2722-9718

Published by Cipanas Theological Seminary

sudah menjadi ciri khas keumatan Israel. Dengan demikian Yerusalemlah yang menjadi tempat untuk menyerukan atau mengabarkan Injil ke segala penjuru dunia. Hal ini agaknya didukung oleh Whybray, yang mengatakan bahwa Yerusalem digambarkan sebagai utusan atau pemberita. ${ }^{9}$

Firman yang disampaikan itu berhubungan erat dengan keadaan sejarah yang dialami nabi dengan orang-orang sezamannya. Ketika Yerusalem dan Bait Allah dihancurkan Nebukadnezar, Raja Babel pada tahun $587 \mathrm{sM},{ }^{10}$ ketika itu pula kerajaan Yehuda sebagai negara yang berdaulat berakhir. Sebagian bangsa Yehuda dibuang ke Babel secara bertahap. Kejatuhan Yerusalem dan Bait Allah sangat memengaruhi keyakinan umat akan peranan Tuhan dalam sejarah Israel. Keadaan sosial ekonomi mereka yang dibuang ke Babel sebenarnya tidak terlalu buruk. Namun dalam kehidupan keagamaan mereka sangat menderita dan kekalahan itu merupakan pukulan berat bagi keyakinan agamanya. Sebagian umat melihat peristiwa itu sebagai kekalahan Tuhan terhadap dewa-dewa Babel. Mereka yang dibuang ke Babel beranggapan bahwa mereka terpisah sangat jauh dari pemeliharaan Tuhan. Karena itu, sebagian mereka berusaha mencari pertolongan lain yaitu para dewa/dewi Babel. Namun sebagian dari mereka tetap setia kepada Tuhan. Mereka yang setia ini menilai bahwa tragedi yang dialami bangsa Israel merupakan hukuman Tuhan atas dosa-dosa bangsa itu sesuai dengan berita-berita para nabi sebelumnya. Di pihak lain mereka juga sedang menantikan keselamatan yang akan datang setelah penghukuman berlaku atas mereka. Deutero Yesaya adalah nabi yang hidup di tengah-tengah situasi penantian itu. Ketika itulah nabi mendengarkan kabar baik ( $b s r)$ atau Injil itu tidak lagi disertai embel-embel penghukuman. Pemberitaan nabi bertujuan meyakinkan umat bahwa Tuhan adalah satu-satunya Allah yang akan memberikan kelepasan kepada Israel. Ilah-ilah lain sama sekali tidak mempunyai kuasa untuk mengerjakan dan memberikan kelepasan itu. Perlu pula digarisbawahi bahwa kelepasan bangsa Israel dari Babel bukan karena mereka sudah menjalani hukumannya, tetapi karena waktunya Allah untuk menebus mereka sudah tiba.

Injil itu juga melibatkan bangsa-bangsa lain. Dalam nubuat-nubuat sebelumnya (Yes. 10), bangsa-bangsa lain juga ditempatkan di bawah kekuasaan Allah dalam hubungan dengan

\footnotetext{
${ }^{9}$ R.N. Whybray, Isiah 40-66, NCBC (Grand Rapids: Eerdmans, 1981), 51-52.

${ }^{10}$ Barnabas Ludji, Pemahaman Dasar Perjenjian Lama 2, (Bandung: Bina Media Informasi, 2009), 105.
} 
Vol. 2, No. 1 (2021):44-56

http://journalsttcipanas.ac.id/index.php/NPTRS/

p-ISSN 2722-9726, e-ISSN 2722-9718

Published by Cipanas Theological Seminary

kedudukan mereka sebagai alat untuk menghukum umat Allah. Walaupun pada akhirnya mereka juga menjadi sasaran penghukuman Allah (Yes. 14:24-27). Dalam pemberitaan Deutero Yesaya, bangsa lain juga ditempatkan di bawah kekuasaan Allah. Namun kali ini bukan sebagai utusan Allah yang melaksanakan penghukuman Allah atas umat Allah, melainkan menjadi utusan Allah yang menjalankan tugas penyelamatan Allah atas umat di pihak lain, dan sebagai utusan yang menjalankan hukuman atas Babel. Karena itu dalam Yesaya 41-48 banyak harapan yang ditujukan kepada Cyrus/Koresy dari Persia.

Berita Injil yang dimaksudkan Deutero Yesaya sepenuhnya bergantung pada anugerah Allah saja. Tuhan menyelamatkan Israel, sebab Ia mengasihi umat-Nya. Berhubungan dengan tujuan penyelamatan itu, Deutero Yesaya menilai penghukuman Tuhan atas umat-Nya merupakan dimensi lain dari keselamatan itu sendiri.

Karya penyelamatan Allah atas Israel itu mempunyai efek pengutusan bagi umat, yaitu, umat akan menjadi saksi dan alat yang menyatakan kemuliaan Allah. Tugas pengutusan itu tergambar dalam kedudukan umat sebagai hamba Tuhan $(41: 8,9 ; 42: 19 ; 44: 2,8,21 ; 48: 6,20)$. Israel akan menjadi saksi yang akan menyatakan kepada bangsa-bangsa dan dunia bahwa hanya Tuhan satu-satunya yang menyelamatkan Israel. Dengan kesaksian itu, semua bangsa akan mengenal dan menyembah Tuhan. Dengan demikian kabar baik yang berpusat pada Israel mempunyai tujuan yang universal dan mengandung pengakuan akan Tuhan sebagai satusatunya Allah Israel dan bangsa-bangsa.

Gambaran tentang Injil keselamatan itu secara garis besar sudah dibentangkan pada awal Deutero Yesaya (40:3-5). Nabi diperkenankan untuk menyaksikan peristiwa-peristiwa yang mengguncangkan dunia sesuai dengan berita nabi. Berita pertama yang terdengar ialah, kebebasan dan kelepasan Yerusalem. Hal ini ditandai dengan pembangunan jalan bagi Tuhan (40:3). Jalan yang dipersiapkan untuk Tuhan bertujuan pawai kemuliaan dan kehebatan Tuhan yang mengerjakan keselamatan bagi umat-Nya. Tindakan penyelamatan Tuhan yang diawali pada berita pasal 40 dilanjutkan dalam pasal-pasal berikutnya.

Untuk menyatakan kehebatan karya penyelamatan Allah, nabi menggunakan pengakuan iman Israel yang tua, ${ }^{11}$ yaitu peristiwa keluaran, Sion, penciptaan, dll. Semua pengakuan iman itu mendapat penafsiran baru dalam konteks waktu itu. Misalnya, nabi

${ }^{11}$ Gerhard Von Rad, The Old Testament Theology, vol. I (New York: Harper \& Row, 1962), 176. 
Vol. 2, No. 1 (2021):44-56

http://journalsttcipanas.ac.id/index.php/NPTRS/

p-ISSN 2722-9726, e-ISSN 2722-9718

Published by Cipanas Theological Seminary

menggunakan pengakuan iman keluaran $(43: 16,18-21 ; 48: 20 ; 51: 10 ; 52: 12)$ bukan sekadar mengingatkan kembali peristiwa-peristiwa yang terjadi sebelumnya, melainkan untuk meyakinkan umat akan datangnya tindakan penyelamatan Allah dalam peristiwa eksodus (keluaran yang baru). Sebuah jalan raya akan dibangun mulai dari Babel menuju Sion. Dalam perjalanan itu, Tuhan akan menjadi pendahulu dan memimpin umat (52:12). Perjalanan pawai dan pesta keselamatan ini juga akan menjadi kesaksian tentang kemuliaan/keagungan Tuhan, sehingga semua bangsa akan mengenal dan menyembah Tuhan.

Bagi nabi, karya penyelamatan Allah melalui peristiwa keluaran baru mempunyai kaitan erat dengan pembangunan kembali kota Sion. Kota Sion akan dibangun kembali oleh Tuhan atas dasar kebenaran-Nya. Peristiwa ini akan merupakan pernyataan yang konkret dari pengampunan Allah atas Israel (49:14-16; 50:1-3; 51:17-23; 54:1-10; 55:6,9). Dengan menggunakan tradisi Sion, nabi membayangkan suatu kerajaan merdeka; pembebasan dari pembuangan; dan kesejahteraan pun terjamin. Semuanya itu hanya terjadi karena ada persekutuan yang mesra antara umat dengan Tuhannya. Dengan demikian Sion akan menjadi kota kebenaran yang kemuliaannya akan melebihi Sion yang lama (54:1-3). Di Sionlah Tuhan akan membarui perjanjian-Nya (53:3). Hakikat pembaruan ini ialah belas kasihan Allah yang nyata dalam pengampunan-Nya atas Israel. Nabi juga menekankan bahwa kebesaran perbuatan Allah atas Sion merupakan kebesaran seorang raja yang mengatasi raja-raja dunia. Gelar raja ini adalah wajar, karena kuasa Tuhan yang nyata dalam karya penyelamatan Allah melalui pembangunan kembali kota Sion. Gelar raja yang dikenakan kepada Tuhan bermaksud menentang agama Babel yang menganggap Marduk sebagai raja. Gelar ini sebenarnya berakar pada pemahaman Israel sendiri. Bagi bangsa Israel, Tuhan sebagai raja merupakan penguasa tunggal dalam persekutuan umat di Sion.

Seperti yang dijelaskan sebelumnya bahwa Injil keselamatan Israel ini bersifat universal, hal yang sama tampak dalam keselamatan kota Sion. Di Sion bangsa-bangsa akan menyaksikan kemuliaan Allah (52:10). Dengan demikian Injil keselamatan yang ditujukan kepada Israel melibatkan umat manusia dari seluruh bangsa dalam karya penyelamatan Allah.

Penegasan nabi terhadap Injil keselamatan itu tampak pula melalui penafsirannya terhadap pokok pengakuan iman penciptaan. Nabi mengangkat riwayat penciptaan dalam konteks penciptaan Israel baru yang terjadi ketika Allah mengampuni dan menebus umat Allah dari 
Vol. 2, No. 1 (2021):44-56

http://journalsttcipanas.ac.id/index.php/NPTRS/

p-ISSN 2722-9726, e-ISSN 2722-9718

Published by Cipanas Theological Seminary

pembuangan di Babel. Di samping itu, dengan mengangkat tradisi penciptaan, nabi juga bermaksud menegaskan tentang kedudukan Tuhan sebagai pemilik dunia dan segenap isinya termasuk bangsa-bangsa yang terlibat dalam kancah sejarah waktu itu, seperti Babel dan Persia. Dengan demikian Tuhan Israel tidak dapat dibandingkan dengan para ilah bangsa lain. Hanya Allah Israel yang mampu menciptakan sejarah baru dan menebus Israel (44:24;54:5). Dari penjelasan di atas dapat kita memahami bahwa Injil yang dimaksudkan nabi dalam Yesaya 52:7 ialah keselamatan Israel dan bangsa-bangsa melalui pengampunan dan penebusan Allah semata-mata. Keselamatan itu meliputi antara lain persekutuan mesra dengan Allah dan persekutuan antar bangsa, pembebasan dari penawanan di Babel.

Marie Barth telah memastikan bahwa pasal 40:1-11 adalah Injil keselamatan atau syalom. Ia membuktikannya dengan memaparkan bagaimana para penulis Injil, dalam keempat Injil mengenakan ayat-ayat ini kepada peristiwa-peristiwa Yesus. Demikian juga Surat Yakobus. $^{12}$

\section{Injil dalam Trito Yesaya}

"Roh Tuhan Allah ada padaku, oleh karena Tuhan telah mengurapi aku; Ia telah mengutus aku untuk menyampaikan kabar baik (basser) kepada orang-orang sengsara (anawim), dan merawat orang-orang yang remuk hati, untuk memberitakan pembebasan kepada orang tawanan, dan kepada orang-orang yang terkurung kelepasan dari penjara, untuk memberitakan tahun rahmat Tuhan dan hari pembalasan Allah kita, untuk menghibur semua orang berkabung" (Yesaya 61:1,2).

Menurut R.N. Whybray, orang yang mengucapkan kata-kata di atas adalah nabi sendiri. Tentu yang dimaksudkan bukanlah Nabi Yesaya yang bernubuat pada abad ke-8 sM, tetapi Nabi Trito Yesaya, ${ }^{13}$ yang namanya juga disembunyikan, seperti Nabi Deutero Yesaya. Hal yang dikatakannya adalah bahwa ia hamba Tuhan. ${ }^{14}$ Selanjutnya Whybray mengatakan bahwa nabi sendiri yang menyatakan bahwa dia diurapi untuk menerima Roh Allah, artinya menerima kuasa untuk menyampaikan kabar baik bagi mereka yang disebut secara jelas pada kedua ayat

\footnotetext{
12 Marie Claire Barth, 63-65.

13 R.N. Whybray, 240.

${ }^{14}$ Barnabas Ludji, 125.
} 
Vol. 2, No. 1 (2021):44-56

http://journalsttcipanas.ac.id/index.php/NPTRS/

p-ISSN 2722-9726, e-ISSN 2722-9718

Published by Cipanas Theological Seminary

di atas. Kata lekraderot yang artinya kebebasan merupakan ungkapan yang berhubungan dengan Tahun Yobel ${ }^{15}$, yang semua peraturannya terdapat dalam Im. 25. ${ }^{16}$

Ayat-ayat di atas merupakan bagian dari Trito Yesaya (Yes. 56-66). Dalam Trito Yesaya, kata $b s r$ agaknya mengalami intensifikasi arti, sebab dalam Trito Yesaya 60:6, kata tersebut dimengerti sebagai kabar masyur perbuatan Tuhan. Di pihak lain dalam Yesaya 61:1-2, kata tersebut digunakan bukan sekadar menyangkut nubuat nabi tentang masa depan, tetapi menyangkut kabar baik bagi orang-orang sengsara/tertindas (lebasser anawim). Pada ayat ini Injil merupakan berita keselamatan bagi orang-orang tertindas dan miskin. Kabar sukacita Allah di sini meliputi perbuatan penyembuhan, pembebasan, penghiburan, keselamatan, dll. Injil di sini berbicara tentang tindakan-tindakan nyata bagi mereka yang sengsara dan tertindas. Injil Trito Yesaya ini kemudian menjadi basis bagi kata kunci euanggelion (Injil) PB. Dalam Matius 4:23 Yesus menekankan hal-hal yang disebutkan Trito Yesaya itu, ketika Yesus berbicara tentang kabar baik kerajaan Allah. Demikian pun Yesus dalam Lukas 4:18,19 menerapkan Yesaya 61:1-2 pada diri Yesus untuk menjelaskan tugas-Nya. Menurut Tuhan Yesus kabar baik itu adalah sama dengan yang dikatakan dalam Yesaya 61:1 dan 2.

Dari beberapa bagian Alkitab PL yang menggunakan kata bsr (Injil), kita dapat mengerti bahwa Injil dalam PL merupakan karya penyelamatan Allah melalui pengampunan dan penebusan Allah atas umat-Nya. Sebagai Injil yang dialami, kabar baik berwujud berbagai ketetapan, peraturan yang menyentuh mereka yang miskin, yang tertindas, yang lemah yang sengsara, yang menderita. Juga menyentuh hewan yang biasanya dieksploitasi oleh manusia untuk pertanian. Perhatikan berbagai peraturan dan ketetapan hari Sabat, Tahun Sabat (tahun rahmat) dan tahun Yobel (tahun pembebasan, tahun rahmat).

Thomas D. Hanks dalam bukunya yang berjudul, God so Loved the Third World, mengatakan bahwa titik kulminasi dari Kerajaan Allah ialah memerhatikan mereka yang

\footnotetext{
${ }^{15}$ Barnabas Ludji, Pemahaman Dasar Perjanjian Lama 1, (Bandung: Bina Media Informasi, 2009), 95. Tahun Yobel tidak ada dalam Kitab Perjanjia (Hukum dalam Kel. 20-23) dan Hukum Deuteronomi (Hukum-hukum dalam UI. 12-26). Tahun Yobel dalam Hukum Kekudusan (Im. 25) yang ditulis para imam menjelang kembalinya bengasa Israel dari Pembuangan di Babel. Jumlah tahun Yobel (50 tahun) dihitung dari tahun pembuangan pertama ke Babel pada tahun 597 sM sampai tahap kembali pertama ke Tanah Perjajian pada tahun 537 sM. Yang jumlahnya juga dihitung dengan 7 kali 7 tahun Sabat menjadi 49 tahun. Tahun kelimapuluh adalah tahun pembebasan itu. Setelah kembali dari pembuangan, makna Tahun Yobel direfleksikan kembali oleh Trito Yesaya dalam Yes. 58. ${ }^{16}$ R. N. Whybray, 240,241.
} 
Vol. 2, No. 1 (2021):44-56

http://journalsttcipanas.ac.id/index.php/NPTRS/

p-ISSN 2722-9726, e-ISSN 2722-9718

Published by Cipanas Theological Seminary

miskin, lemah dan tertindas. Menurut surat Yakobus $(2: 1-7 ; 5: 1-6)$, persaudaraan dalam kekristenan merupakan jawaban Allah bagi kaum tertindas dan miskin. Sama dengan penilaian PL, Surat Yakobus menganggap kemiskinan sebagai skandal, jika kekristenan tidak menerapkan titik kulminasi dari Kerajaan Allah, yaitu memerhatikan dan memenuhi kebutuhan anggota jemaat yang miskin (lihat Yakobus 2:15-16). Dalam hubungan dengan pandangan di atas, Hanks mengatakan bahwa Allah tidak menghukum gereja karena ortodoksinya, melainkan karena gereja tidak memerhatikan tugas-tugas di atas. ${ }^{17}$ Keselamatan itu meliputi semua bangsa walaupun melalui penyelamatan Israel. Lebih jauh bahwa Injil keselamatan itu juga mencakup kelepasan dari keadaan tertindas dan tertawan termasuk orang miskin. Dengan demikian kabar baik dalam PL menyangkut keselamatan (syalom) dalam pengertian yang seluas-luasnya.

"Roh Tuhan ada pada-Ku, oleh sebab Ia telah mengurapi Aku, untuk menyampaikan kabar baik (Injil) kepada orang-orang miskin; dan Ia telah mengutus Aku untuk memberitakan pembebasan kepada orang-orang tawanan dan penglihatan bagi orang-orang buta, untuk membebaskan orang-orang yang tertindas, untuk memberitakan tahun rahmat Tuhan telah datang (Lukas 4:18,19).”

\section{Daftar Pustaka}

Barth, Marie Claire. Tafsiran Alkitab: Kitab Yesaya Fasal 40-55. Jakarta: BPK, 1983.

Baumgärtel, Friedrich. "euggelizomai, euggelion, proeuggelizimai, euggelistes.” Theological Dictionary of the New Testament Vol. II. Ed. Kittel. Grand Rapids: Eerdmans 1964.

Hanks, Thomas D. God So Loved the Third World. New York: Orbis, 1983.

Krauss, Has Joachim. Psalms, 1- 150. Philadelphia: Ausburg, 1981.

Ludji, Barnabas. Pemahaman Dasar Perjanjian Lama 1. Bandung: Bina Media Informasi, 2009.

Ludji, Barnabas. Pemahaman Dasar Perjanjian Lama 2. Bandung: Bina Media Informasi, 2009 .

\footnotetext{
${ }^{17}$ Thomas D. Hanks, God so Loved the Third World, (New York, ORBIS BOOKS, 1983), 46.
} 


\section{The New Perspective in Theology and Religious Studies}

Vol. 2, No. 1 (2021):44-56

http://journalsttcipanas.ac.id/index.php/NPTRS/

p-ISSN 2722-9726, e-ISSN 2722-9718

Published by Cipanas Theological Seminary

Schilling, O. "bsr." Theological Dictionary of the Old Testament Vol. II. Ed. Johannes

Botterweck, Helmer Ringgren. Grand Rapids: Eerdmans, 1975.

Tate, Marvine. Psalms 51-100. WBC. Dallas: Word Books, 1990.

Von Rad, Gerhard. Old Testament Theology Vol. I. New York: Harper \& Row, 1962.

Watts, John D. W. Isiah 34-66. WBC. Dallas: Word Books, 1987.

Whybray, R. N. Isiah 40-66. NCBC. Grand Rapids: Eerdmans, 1981. 